\title{
A clinical trial of two parenteral nutrition solutions in neonates
}

\author{
N McIntosh, V Mitchell
}

\begin{abstract}
Sixty eight neonates requiring total or supplemental parenteral nutrition in the first week of life were randomly allocated either Vamin 9 glucose $(n=34)$ or MB233G $(n=34)$ in a double blind trial. Twenty infants were withdrawn: four because they died before 5 days of age and 16 because the amino acids were required for less than the five days of the trial. The solutions were isocaloric (1.6 MJ/1, 380 $\mathrm{kcal} / \mathrm{l})$ and with the same nitrogen content $(2.79 \mathrm{~g} / \mathrm{l})$ and were infused at rates and volumes determined by clinical staff on the basis on the infants, clinical condition and serum electrolyte biochemistry. There was an excess of deaths in the group treated with Vamin 9 glucose particularly related to babies weighing $\geqslant 1000 \mathrm{~g}$. Infants $<1000 \mathrm{~g}$ receiving the Vamin 9 glucose preparation required amino acids for twice as long. There was no significant difference between the weight losses or head circumference during the study period. Plasma aminograms in the group receiving Vamin 9 glucose showed concentrations of phenylalanine, tyrosine, proline, serine, and aspartic acid to be significantly higher than the reference range. Multiple regression analysis suggested that phenylalanine was the primary abnormality. The intravenous amino acid preparation MB233G maintained the plasma aminogram of newborn infants within the reference range of normal newborn infants.
\end{abstract}

The amino acid preparations used for intravenous nutrition of infants are designed to achieve the plasma amino acid concentrations seen after birth in the full term infant. Whether the aminogram should mimic that of the starved infant, ${ }^{1}$ the infant fed breast milk, ${ }^{2}$ or the infant fed on formula $^{3}$ is open for discussion.

The preterm infant in utero has a very different aminogram in the middle and last trimester to the infant once born. ${ }^{4-7}$ It might be logical to attempt to achieve the plasma aminogram of the fetus in the preterm infant that requires intravenous nutrition if, all other things being equal, there are no signs of toxicity. We have previously reported an observational study on a group of very low birthweight infants intravenously fed with a preparation of crystalline amino acids (MB233G, Cernep Synthelabo) designed to achieve the reported cord concentrations of the infant. ${ }^{5}$ In that study, which was not a randomised comparative study, we showed that the preparation was well tolerated metabolically with plasma aminograms in the desired range even in the smallest infants. ${ }^{8}$
Recently there have been reports that the more commonly used intravenous amino acid preparation in the United Kingdom, Vamin 9 glucose (KabiVitrum), is sometimes associated in very low birthweight infants with potentially toxic amino acid concentrations. It was postulated that this was an idiosyncratic effect in the babies reported. ${ }^{9-12}$ This study reports a double blind randomised controlled trial of Vamin 9 glucose and MB233G in infants in the first week of life.

\section{Patients and methods}

From August 1986 to July 1987, 68 infants admitted to the South West Thames Regional Neonatal Intensive Care Unit at St George's Hospital, London, received intravenous amino acids during the first week of life. Prescription of parenteral support (partial or total) was by the attending clinician based on his assessment of the baby's inability to tolerate adequate nutritional support by the enteral route. These infants were randomly allocated to either Vamin 9 glucose or MB233G by pharmacy staff. Both preparations were prepared by the pharmacy in clear, orange plastic bags and giving sets as Vamin 9 glucose has a yellow colour but MB233G is colourless. A pilot study made it clear that this satisfactorily masked the nature of the preparation. The random allocation (blind to the clinical staff) was stratified to babies above and below $1000 \mathrm{~g}$ birth weight by the pharmacy staff. Both preparations contained the same total density of nitrogen $(2 \cdot 79$ $\mathrm{g} / \mathrm{l})$ and energy $(1.59 \mathrm{MJ} / \mathrm{l}, 380 \mathrm{kcal} / \mathrm{l})$ but the differences in the amino acid constituents are shown in fig 1 . The volume of infusion and electrolyte content were decided daily by the clinical staff on the basis of the clinical course and the results of the electrolyte determinations in the plasma. The amino acid (and lipid solutions) were infused continuously over 24 hours usually by peripheral infusion. Plasma amino acids and liver function tests were performed on day 1 before the start of the infusion and between 0800 and 1000 hours on day 5 if the patient was still alive and still receiving parenteral nutrition.

Small quantities of milk - either maternal expressed breast milk or preterm formula (Preaptamil, Milupa) or both-were introduced from day 1 by nasogastric tube in an attempt to promote biliary flux.

Statístical analyses were performed only for patients for whom parenteral nutrition lasted for at least five days.

Efficacy of the preparations was assessed by body weight and head circumference measure- 


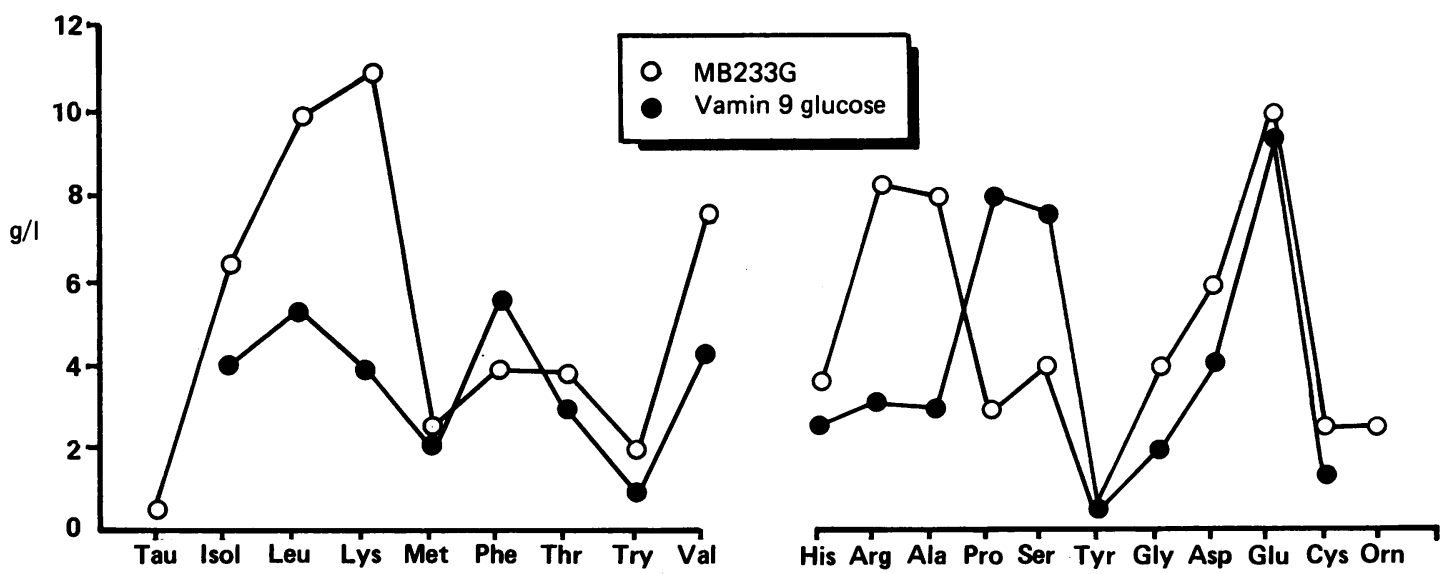

Figure 1 Amino acid concentrations in the two amino acid preparations divided according to whether they are essential (left) or non-essential (right). Tau: taurine, isol: isoleucine, leu: leucine, lys: lysine, met: methionine, phe: phenylalanine, thr: threonine, try: tryptophan, val: valine, his: histidine, arg: arginine, ala: alanine, pro: proline, ser: serine, tyr: tyrosine, gly: glycine, asp: aspartic acid, glu: glutamine, cys: cysteine, orn: ornithine.

ments and by analysis of plasma aminograms. The heparinised blood samples for the aminograms were immediately separated in a microfuge (Beckman). The plasma was deproteinised with sulphosalicylic acid ( $25 \mathrm{mg} / \mathrm{ml}$ plasma) and remicrofuged, the supernatant being then stored at $-70^{\circ} \mathrm{C}$ until analysed on a Biotronik 5001 amino acid analyser.

Tolerance of the preparation was examined clinically and by frequent (at least daily) analysis of blood urea, electrolytes and haematology and acid base. Liver function tests were performed at the start and after five days of amino acid infusion.

Intravenous nitrogen, amino acid, energy, and volume intakes were compared as were the oral intakes of nitrogen, protein, energy, and volume in the two groups. Baseline data were analysed by Student's $t$ test (on the ranked values) and categorical parameters by the $\chi^{2}$ test or Fisher's exact test. Analysis of variance, stepwise regression analysis, and correlation were also performed on the ranked groups. Significance was defined as a $p$ value less than 0.05 . Computations and analyses were performed on SAS statistical software.

Comparisons of the amino acids in the two groups was by Wilcoxon's signed ranks test. Significance here was defined as a $p$ value less than $0 \cdot 01$. When a significant difference in a particular plasma amino acid was established between the two nutritional regimes we looked for correlation between the plasma concentration and the total amino acid intake over the previous day.

The study received ethical approval from the St George's Hospital Medical ethics committee and informed consent was obtained from the parents.

\section{Results}

Intravenous nutrition was used in these infants only when they were unable to tolerate enteral feeds because of extreme immaturity or biological instability. Twenty of the 68 babies entered into the study were excluded from the analysis because the amino acid infusion was for less than five days: four babies died before the age of 5 days (one on Vamin 9 glucose, three on MB233G) and 16 babies required parenteral nutrition for less than the five day study period (eight on each preparation). This left 23 babies $(\mathrm{n}=7,<1000 \mathrm{~g})$ allocated to MB233G and 25 babies $(n=11,<1000 \mathrm{~g})$ allocated to Vamin 9 glucose for analysis (table 1) after five completed days of intravenous nutrition.

In some of the smallest infants biochemical evaluation was less frequent than was envisaged in the study protocol for reasons of small blood volume.

\section{COMPARABILITY OF THE GROUPS}

The birthweight stratification and the weights and gestations of the babies on the two preparations were comparable and the size and maturities of the babies stratified above and below $1000 \mathrm{~g}$ are not appreciably different in the two nutrition groups (table 1). The clinical problems of the babies in the two groups are shown in table 2 . A total of $41(85 \%)$ of the babies were ventilated at the time of entry to the study and $27(52 \%)$ were still ventilated on the sixth day when the study period was terminated. Despite

Table 1 Details of babies. Results are mean (SD)

\begin{tabular}{|c|c|c|c|c|}
\hline & No of babies & $\begin{array}{l}\text { Gestation } \\
\text { (days) }\end{array}$ & $\begin{array}{l}\text { Birth weight } \\
(\mathrm{g})\end{array}$ & $\begin{array}{l}\text { Average length of } \\
\text { parenteral nutrition } \\
\text { (days) }\end{array}$ \\
\hline $\begin{array}{l}\text { MB233G } \\
\text { Vamin } 9 \text { glucose }\end{array}$ & $\begin{array}{r}7 \\
11\end{array}$ & $\begin{array}{l}\text { Weighing }<1000 \mathrm{~g} \\
191 \text { (13) } \\
187(10)\end{array}$ & $\begin{array}{l}806(164) \\
742(162)\end{array}$ & $\left.\begin{array}{r}8(2.6) \\
13(6.6)\end{array}\right\} p<0.05$ \\
\hline $\begin{array}{l}\text { MB233G } \\
\text { Vamin } 9 \text { glucose }\end{array}$ & $\begin{array}{l}16 \\
14\end{array}$ & $\begin{array}{l}\text { Weighing } \geqslant 1000 \mathrm{~g} \\
227(28) \\
216(30)\end{array}$ & $\begin{array}{l}1844(884) \\
1767(939)\end{array}$ & $\begin{array}{l}14(8 \cdot 0) \\
14(7 \cdot 5)\end{array}$ \\
\hline
\end{tabular}


Table 2 Incidence of acute clinical problems. Results are number (\%)

\begin{tabular}{lccc}
\hline & $M B 233 G(n=23)$ & Vamin glucose $(n=25)$ & $p$ Value \\
\hline Hyaline membrane disease & $15(65)$ & $19(76)$ & $0 \cdot 45$ \\
Ventilated at start of end period & $18(78)$ & $23(92)$ & $0 \cdot 2$ \\
Ventilated at end of study period & $11(48)$ & $16(64)$ & $0 \cdot 35$ \\
Air leaks & $2(9)$ & $6(24)$ & $0 \cdot 17$ \\
Abnormal neurological signs & $3(13)$ & $5(20)$ & $0 \cdot 5$ \\
Appreciable sepsis & $9(39)$ & $8(32)$ & $0 \cdot 6$ \\
Jaundice (physiological) & $10(43)$ & $10(40)$ & $0 \cdot 8$ \\
Patent ductus arteriosus & $6(26)$ & $3(12)$ & $0 \cdot 2$ \\
\hline
\end{tabular}

"By $\chi^{2}$ with Yates's correction or Fisher's exact test: all $\mathrm{p}$ values are non-significant.

Table 3 Nutritional intakes on first and last study day. Results are mean (SEM)

\begin{tabular}{|c|c|c|c|c|c|}
\hline & & Day 1 & $*$ & Day 5 & $*$ \\
\hline $\begin{array}{l}\text { Intravenous volume }(\mathrm{ml} / \mathrm{kg} / \text { day }) \\
\text { Intravenous amino acids }(\mathrm{g} / \mathrm{kg} / \text { day }) \\
\text { Intravenous energy }(\mathrm{MJ} / \mathrm{kg} / \text { day }) \\
\text { Intravenous nitrogen }(\mathrm{g} / \mathrm{kg} / \text { day }) \\
\text { Total volume }(\mathrm{ml} / \mathrm{kg} / \mathrm{day}) \\
\text { Total oral amino acids }(\mathrm{g} / \mathrm{kg} / \text { day) } \\
\text { Total energy }(\mathrm{MJ} / \mathrm{kg} / \mathrm{day}) \\
\text { Total nitrogen }(\mathrm{g} / \mathrm{kg} / \text { day })\end{array}$ & $\begin{array}{l}\text { MB233G } \\
\text { Vamin } 9 \text { glucose } \\
\text { MB233G } \\
\text { Vamin } 9 \text { glucose } \\
\text { MB233G } \\
\text { Vamin } 9 \text { glucose } \\
\text { MB233G } \\
\text { Vamin } 9 \text { glucose } \\
\text { MB233G } \\
\text { Vamin } 9 \text { glucose } \\
\text { MB233G } \\
\text { Vamin } 9 \text { glucose } \\
\text { MB233G } \\
\text { Vamin } 9 \text { glucose } \\
\text { MB233G } \\
\text { Vamin } 9 \text { glucose }\end{array}$ & $\begin{array}{l}101(6) \\
95(8) \\
0.29(0.04) \\
0.32(0.06) \\
0.14(0.01) \\
0.13(0.01) \\
0.04(0.007) \\
0.05(0.009) \\
107(6) \\
104(8) \\
0.36(0.05) \\
0.42(0.06) \\
0.17(0.02) \\
0.17(0.02) \\
0.05(0.01) \\
0.06(0.01)\end{array}$ & $\begin{array}{l}\text { NS } \\
\text { NS } \\
\text { NS } \\
\text { NS } \\
\text { NS } \\
\text { NS } \\
\text { NS } \\
\text { NS }\end{array}$ & $\begin{array}{l}137(17) \\
127(10) \\
1.44(0.16) \\
1.54(0.15) \\
0.21(0.02) \\
0.18(0.02) \\
0.21(.02) \\
0.23(.02) \\
177(13) \\
161(6) \\
1.87(0.16) \\
1.93(0.15) \\
0.36(0.02) \\
0.33(0.02) \\
0.27(0.02) \\
0.28(0.02)\end{array}$ & $\begin{array}{l}\text { NS } \\
\text { NS } \\
\text { NS } \\
\text { NS } \\
\text { NS } \\
\text { NS } \\
\text { NS } \\
\text { NS }\end{array}$ \\
\hline
\end{tabular}

${ }^{*}$ Column significance: non-paired $t$ test.

randomisation of the intravenous nutrition, it appears that the infants in the group allocated Vamin 9 glucose may have been sicker. The respiratory problems at entry to the trial appear to be worse in the group randomly allocated Vamin 9 glucose with more babies having hyaline membrane disease and more being ventilated. Neither of these features reach significance but the fact that more infants in this group were still requiring ventilation at the end of the study and three times more had developed an air leak by the end of the study (though this trend still does not reach significance) means that the blind allocation may not have been quite as random as was hoped for. Further analysis of acid base and blood gases (submitted to the editor) showed almost identical arterial carbon dioxide tension, $\mathrm{pH}$, and base excess in the two groups even when stratified into the two weight groupings. The infants $<1000 \mathrm{~g}$ showed a trend to higher oxygen requirements and inflation pressures though again these parameters did not reach significance. Conversely, twice as many infants in the group on MB233G developed a patent ductus arteriosus; again this trend did not reach significance.

\section{NUTRITIONAL INTAKE}

The nutritional intakes are shown for the two groups in table 3. The energy, amino acid, and nitrogen provision given intravenously and the total amino acid and nitrogen intakes were similar in the two groups. The total volume and energy intakes were significantly higher on day 4 (not tabulated) in the group receiving MB233G. This was due to two infants, both less than $1000 \mathrm{~g}$ birth weight who had extra $5 \%$ dextrose intravenously because of large transcutaneous fluid losses. The volume and energy intakes on the other days of the study were simi- lar. A $10 \%$ intralipid solution was introduced at $0.5 \mathrm{ml} / \mathrm{kg} /$ hour when clinical jaundice began to wane. As the trial involved only the first five days of life, in both groups this formed only a minor contribution to the total energy intake.

\section{BIOLOGICAL EFFICACY}

The efficacy of the solution was assessed clinically by the weight and head circumference changes over the time of the study (table 4). The weight losses in the two groups were similar and not unusual for the unit or babies of this gestation and size. The head circumference changes were similar in the two groups.

\section{PLASMA AMINOGRAMS}

Fourteen babies on MB233G and 16 babies on Vamin 9 glucose had plasma aminograms measured on the fifth day of parental nutrition. Eighteen (nine in each group) were not analysed due to lack of sufficient plasma $(n=12)$ or wrong date of sampling $(n=6)$. The individual data are shown in table 5 and the summary of the analysed aminograms is shown in fig 2 . The graphic representation of the complete aminograms are given by 'stars' that show the mean

Table 4 Weight and head circumference changes

\begin{tabular}{|c|c|c|c|}
\hline & \multirow[t]{2}{*}{$\underset{\text { (range) }}{\text { Mean }}(\%)$ weight loss } & \multicolumn{2}{|c|}{$\begin{array}{l}\text { Mean (SEM) head } \\
\text { circumferences }(\mathrm{cm})\end{array}$} \\
\hline & & Day 1 & Day 5 \\
\hline \multicolumn{4}{|c|}{$M B 233 G$} \\
\hline $\begin{array}{l}<1000 \mathrm{~g} \\
\geqslant 1000 \mathrm{~g}\end{array}$ & $\begin{array}{l}-4 \cdot 8(-7 \cdot 3 \text { to }-1 \cdot 5) \\
-0.6(-11 \text { to }+11)\end{array}$ & $28 \cdot 6(1)$ & $26 \cdot 7(0 \cdot 9)$ \\
\hline \multicolumn{4}{|c|}{ Vamin 9 glucose } \\
\hline $\begin{array}{l}<1000 \mathrm{~g} \\
\geqslant 1000 \mathrm{~g}\end{array}$ & $\begin{array}{l}-2 \cdot 5(-10 \text { to }+13) \\
-3 \cdot 5(-19 \text { to }+5 \cdot 5)\end{array}$ & $25 \cdot 8(1)$ & $26 \cdot 7(0 \cdot 9)$ \\
\hline
\end{tabular}

These differences are not significant. 
Table 5 Plasma amino acids at day 5 ( $\mu$ molll). Results are mean (SD)

\begin{tabular}{|c|c|c|c|c|c|c|}
\hline & & No of babies & $M B 233 G$ & No of babies & Vamin 9 glucose & Normal range \\
\hline Leucine & $\begin{array}{l}<1000 \mathrm{~g} \\
\geqslant 1000 \mathrm{~g}\end{array}$ & $\begin{array}{l}5 \\
9\end{array}$ & $\begin{array}{r}97 \cdot 6(47 \cdot 8) \\
140 \cdot 7(65 \cdot 2)\end{array}$ & $\begin{array}{l}8 \\
8\end{array}$ & $\begin{array}{l}142.9(67 \cdot 8) \\
134.5(50 \cdot 6)\end{array}$ & $82 \cdot 7-187 \cdot 3$ \\
\hline Isoleucine & $\begin{array}{l}<1000 \mathbf{g} \\
\geqslant 1000 \mathrm{~g}\end{array}$ & $\begin{array}{l}5 \\
9\end{array}$ & $\begin{array}{l}17 \cdot 2(27 \cdot 6) \\
71 \cdot 2(39 \cdot 3)\end{array}$ & $\begin{array}{l}\circ \\
8 \\
8\end{array}$ & $\begin{array}{r}79.6(47.6) \\
85.6(30 \cdot 6)\end{array}$ & $36 \cdot 4-107 \cdot 6$ \\
\hline Valine & $\begin{array}{l}<1000 \mathrm{~g} \\
\geqslant 1000 \mathrm{~g}\end{array}$ & $\begin{array}{l}5 \\
9\end{array}$ & $\begin{array}{l}175.1(67 \cdot 2) \\
240.3(99 \cdot 5)\end{array}$ & $\begin{array}{l}\circ \\
8 \\
8\end{array}$ & $\begin{array}{l}244.5(76 \cdot 1) \\
272.5(75.9)\end{array}$ & $171 \cdot 8-314 \cdot 2$ \\
\hline Methionine & $\begin{array}{l}<1000 \mathrm{~g} \\
\geqslant 1000 \mathrm{~g}\end{array}$ & $\begin{array}{l}9 \\
5 \\
9\end{array}$ & $\begin{array}{r}240.3(99 \cdot 5) \\
30.5(15 \cdot 5) \\
39 \cdot 4(15 \cdot 8)\end{array}$ & $\begin{array}{l}8 \\
8 \\
8\end{array}$ & $\begin{array}{r}27.5(15.9) \\
46.8(15 \cdot 6) \\
54.6(15 \cdot 3)\end{array}$ & $20 \cdot 4-49 \cdot 7$ \\
\hline Cysteine & $\begin{array}{l}\geqslant 1000 \mathrm{~g} \\
<1000 \mathrm{~g} \\
\geqslant 1000 \mathrm{~g}\end{array}$ & $\begin{array}{l}9 \\
5 \\
9\end{array}$ & $\begin{array}{l}39.4(15.8) \\
15.4(5.8) \\
34.5(8.4)\end{array}$ & $\begin{array}{l}8 \\
8 \\
8\end{array}$ & $\begin{array}{l}54 \cdot 6(15 \cdot 3) \\
32 \cdot 8(18 \cdot 8) \\
49 \cdot 6(24 \cdot 2)\end{array}$ & $32 \cdot 4-57 \cdot 6$ \\
\hline Taurine & $\begin{array}{l}=1000 \mathrm{~g} \\
\mathbf{g}\end{array}$ & $\begin{array}{l}9 \\
5 \\
0\end{array}$ & $\begin{array}{r}90 \cdot 8(34 \cdot 7) \\
14 \cdot 6(69 \cdot 4)\end{array}$ & $\begin{array}{l}8 \\
8 \\
8\end{array}$ & $\begin{array}{l}110.0(96 \cdot 4) \\
119.6(115 \cdot)\end{array}$ & $115 \cdot 1-378 \cdot 9$ \\
\hline Phenylalanine & $\begin{array}{l}\geqslant 1000 \mathrm{~g} \\
<1000 \mathrm{~g}\end{array}$ & $\begin{array}{l}9 \\
5\end{array}$ & $\begin{array}{r}142.6(69 \cdot 4) \\
86.4(15 \cdot 8)\end{array}$ & $\begin{array}{l}8 \\
8 \\
8\end{array}$ & $\begin{array}{l}194.6(113 \cdot 1) \\
206 \cdot 1(73 \cdot 0)\end{array}$ & $48 \cdot 9-99 \cdot 1$ \\
\hline Tyrosine & $\begin{array}{l}\geqslant 1000 \mathrm{~g} \\
<1000 \mathrm{~g}\end{array}$ & $\begin{array}{l}9 \\
5\end{array}$ & $\begin{array}{l}89 \cdot 4(33 \cdot 0) \\
91 \cdot 4(100 \cdot 0)\end{array}$ & $\begin{array}{l}8 \\
8\end{array}$ & $\begin{array}{l}198 \cdot 3(68 \cdot 7) \\
368 \cdot 7(309 \cdot 7)\end{array}$ & $35 \cdot 8-90 \cdot 2$ \\
\hline Lysine & $\begin{array}{l}\geqslant 1000 \mathrm{~g} \\
<1000 \mathrm{~g}\end{array}$ & $\begin{array}{l}9 \\
5\end{array}$ & $\begin{array}{r}61.3(51 \cdot 6) \\
195.9(93.5)\end{array}$ & $\begin{array}{l}8 \\
8\end{array}$ & $\begin{array}{l}386 \cdot 1(372 \cdot 7) \\
198 \cdot 2(88 \cdot 7)\end{array}$ & $216 \cdot 4-467 \cdot 6$ \\
\hline & $\geqslant 1000 \mathrm{~g}$ & 9 & $322 \cdot 1(151 \cdot 7)$ & 8 & $201 \cdot 1(84 \cdot 4)$ & \\
\hline Threonine & $<1000 \mathrm{~g}$ & $\begin{array}{l}5 \\
9\end{array}$ & $\begin{array}{l}144 \cdot 2(40 \cdot 2) \\
182 \cdot 7(74 \cdot 1)\end{array}$ & $\begin{array}{l}8 \\
8\end{array}$ & $\begin{array}{l}281 \cdot 1(125 \cdot 6) \\
299 \cdot 1(133 \cdot 8)\end{array}$ & $161 \cdot 3-374 \cdot 7$ \\
\hline Histidine & $\begin{array}{l}<1000 \mathrm{~g} \\
\geqslant 1000 \mathrm{~g}\end{array}$ & $\begin{array}{l}5 \\
9\end{array}$ & $\begin{array}{r}88 \cdot 8(26 \cdot 8) \\
119 \cdot 0(45 \cdot 7)\end{array}$ & $\begin{array}{l}8 \\
8 \\
8\end{array}$ & $\begin{array}{l}121 \cdot 1(44 \cdot 1) \\
117 \cdot 8(29 \cdot 2)\end{array}$ & $63 \cdot 4-180 \cdot 6$ \\
\hline Arginine & $\begin{array}{l}<1000 \mathrm{~g} \\
\geqslant 1000 \mathrm{~g}\end{array}$ & $\begin{array}{l}5 \\
9\end{array}$ & $\begin{array}{l}46.7(33 \cdot 8) \\
90 \cdot 3(52 \cdot 3)\end{array}$ & $\begin{array}{l}8 \\
8\end{array}$ & $\begin{array}{l}54 \cdot 3(44 \cdot 5) \\
49 \cdot 0(23 \cdot 5)\end{array}$ & $47 \cdot 5-114 \cdot 5$ \\
\hline Aspartic acid & $\begin{array}{l}<1000 \mathrm{~g} \\
\geqslant 1000 \mathrm{~g}\end{array}$ & $\begin{array}{l}5 \\
9\end{array}$ & $\begin{array}{l}16 \cdot 8(10.4) \\
40.1(50.9)\end{array}$ & $\begin{array}{l}8 \\
8\end{array}$ & $\begin{array}{l}61.5(70.3) \\
51.7(32.9)\end{array}$ & $6.4-35.7$ \\
\hline Serine & $<1000 \mathrm{~g}$ & $\begin{array}{l}5 \\
9\end{array}$ & $\begin{array}{l}131.9(36 \cdot 0) \\
197 \cdot 0(66 \cdot 2)\end{array}$ & $\begin{array}{l}8 \\
8 \\
8\end{array}$ & $\begin{array}{l}315 \cdot 1(167 \cdot 7) \\
344 \cdot 1\end{array}(183 \cdot 1)$ & $143 \cdot 4-214 \cdot 6$ \\
\hline Asparagine & $<1000 \mathrm{~g}$ & $\begin{array}{l}5 \\
9\end{array}$ & $\begin{array}{l}22.8(13.4) \\
23.3(18.9)\end{array}$ & $\begin{array}{l}8 \\
8 \\
8\end{array}$ & $\begin{array}{l}24 \cdot 4(12 \cdot 3) \\
28 \cdot 9(25 \cdot 7)\end{array}$ & $28 \cdot 4-53 \cdot 6$ \\
\hline Glutamic acid & $<1000 \mathrm{~g}$ & $\begin{array}{l}5 \\
5 \\
9\end{array}$ & $\begin{array}{r}55 \cdot 2(15 \cdot 4) \\
10 \cdot 0(130 \cdot 6)\end{array}$ & $\begin{array}{l}\circ \\
8 \\
8\end{array}$ & $\begin{array}{l}204 \cdot 7(156 \cdot 5) \\
192.4(150.5)\end{array}$ & $58 \cdot 3-313 \cdot 7$ \\
\hline Glutamine & $<1000 \mathrm{~g}$ & $\begin{array}{l}5 \\
9\end{array}$ & $\begin{array}{l}328.1(111 \cdot 2) \\
710 \cdot 3(680 \cdot 5)\end{array}$ & $\begin{array}{l}8 \\
8\end{array}$ & $\begin{array}{l}321.3(131.4) \\
432.5(130.6)\end{array}$ & $219 \cdot 3-834 \cdot 7$ \\
\hline Proline & $<1000 \mathrm{~g}$ & $\begin{array}{l}5 \\
9\end{array}$ & $\begin{array}{l}126 \cdot 6(88 \cdot 2) \\
200 \cdot 9(72 \cdot 2)\end{array}$ & $\begin{array}{l}8 \\
8 \\
8\end{array}$ & $\begin{array}{l}411 \cdot 5(169 \cdot 4) \\
478 \cdot 3(211 \cdot 1)\end{array}$ & $10 \cdot 7-252 \cdot 4$ \\
\hline Glycine & $\begin{array}{l}<1000 \mathrm{~g} \\
\geqslant 1000 \mathrm{~g}\end{array}$ & $\begin{array}{l}5 \\
9\end{array}$ & $\begin{array}{l}216 \cdot 8(54 \cdot 1) \\
335 \cdot 7(108 \cdot 8)\end{array}$ & $\begin{array}{l}8 \\
8 \\
8\end{array}$ & $\begin{array}{l}35.6(101 \cdot 8) \\
417 \cdot 2(177 \cdot 6)\end{array}$ & $199 \cdot 9-338 \cdot 1$ \\
\hline Alanine & $\begin{array}{l}=1000 \mathrm{~g} \\
\geqslant 1000\end{array}$ & $\begin{array}{l}5 \\
9 \\
9\end{array}$ & $\begin{array}{l}224.8(114.8) \\
306 \cdot 3(176.0)\end{array}$ & $\begin{array}{l}8 \\
8 \\
8\end{array}$ & $\begin{array}{l}285.5(136 \cdot 8) \\
379 \cdot 7(228.0)\end{array}$ & $281 \cdot 0-595 \cdot 0$ \\
\hline Citrulline & $\begin{array}{l}\geqslant 1000 \mathrm{~g} \\
<1000 \mathrm{~g}\end{array}$ & 5 & $\begin{array}{c}306 \cdot 3(176 \cdot 0) \\
7 \cdot 2(3 \cdot 6)\end{array}$ & $\begin{array}{l}8 \\
8 \\
8\end{array}$ & $\begin{array}{l}14 \cdot 6(4 \cdot 7) \\
1.90)\end{array}$ & $2 \cdot 0-55 \cdot 0$ \\
\hline Ornithine & $\begin{array}{l}\geqslant 1000 \mathrm{~g} \\
<1000 \mathrm{~g} \\
\geqslant 1000 \mathrm{~g}\end{array}$ & $\begin{array}{l}9 \\
5 \\
9\end{array}$ & $\begin{aligned} 8 \cdot 8 & (4 \cdot 2) \\
80 \cdot 0 & (49 \cdot 4) \\
137 \cdot 3 & (71 \cdot 6)\end{aligned}$ & $\begin{array}{l}8 \\
8 \\
8\end{array}$ & $\begin{array}{l}15 \cdot 0(11 \cdot 1) \\
78 \cdot 4(54 \cdot 3) \\
98 \cdot 0(75 \cdot 0)\end{array}$ & $45 \cdot 4-162 \cdot 6$ \\
\hline
\end{tabular}

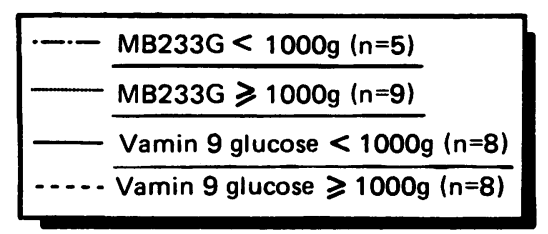

Figure 2 Plasma aminogram of study babies on day 5 . The reference ranges indicated are the concentrations in umbilical cord blood of normal full term newborn infants. ${ }^{5}$ Glu: glutamic acid, gln: glutamine, asn: asparagine, ser: serine, thr: threonine, asp: aspartic acid, tau: taurine, arg: arginine, try: tryptophan, his: histidine, lys: lysine, orn: ormithine, cit: citrulline, phe: phenylalanine, tyr: tyrosine, leu: leucine, isol: isoleucine, met: methionine, cys: cysteine, val: valine, ala: alanine, gly: glycine, pro: proline.

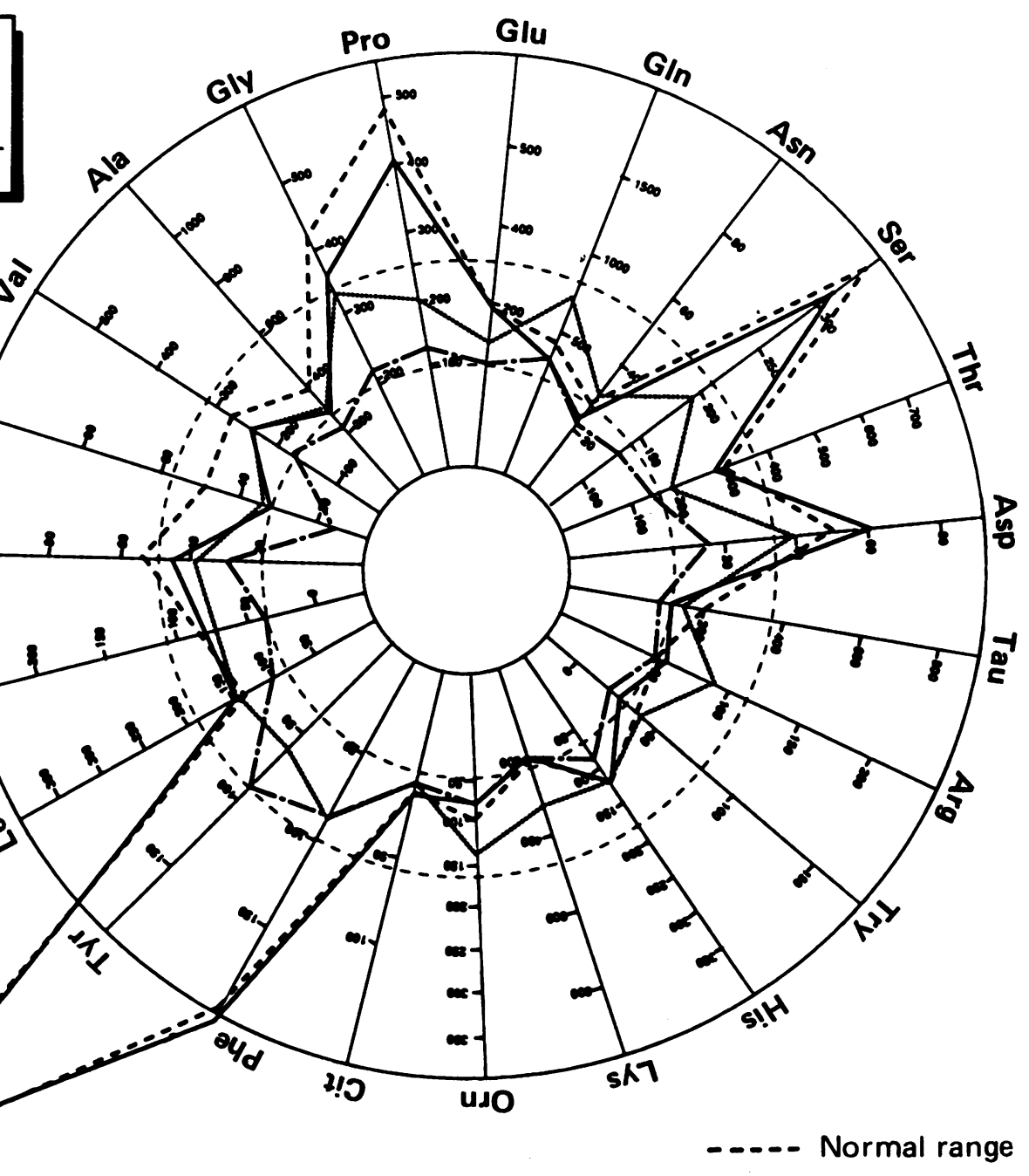


value of each amino acid. The dotted lines represent the reference ranges from cord blood of preterm and term deliveries. ${ }^{5}$ The ranges are seen in table 5 .

The mean values of the branched chain amino acids and the sulphur containing amino acids were similar in the two groups, although some plasma taurine concentrations in the group on Vamin 9 glucose were extremely low (for example-9, 20, $27 \mu \mathrm{mol} / \mathrm{l}$; lower limit of reference range $=115 \mu \mathrm{mol} / \mathrm{l}$ ) and the mean value of the cysteine in the group on MB233G was lower than the reference range for babies less than $1000 \mathrm{~g}$. The mean plasma concentrations of phenylalanine and tyrosine were significantly greater $(p<0.0001$ and $p<0.0003$ respectively) in the group on Vamin 9 glucose. The concentrations in the group Vamin 9 glucose were not related to the body weight of the infant. The mean plasma concentrations of lysine were slightly lower than the lower reference range value $(216 \mu \mathrm{mol} / \mathrm{l})$ in both groups on Vamin 9 glucose $(<1000 \mathrm{~g}=198 \mu \mathrm{mol} / \mathrm{l}, \geqslant 1000 \mathrm{~g}=201$ $\mu \mathrm{mol} / \mathrm{l}$ ) and in the babies $<1000 \mathrm{~g}$ fed MB233G $(196 \mu \mathrm{mol} / \mathrm{l})$. The mean plasma threonine concentrations were in the normal range for all except the group on MB233G weighing $<1000 \mathrm{~g}$. The difference between the two groups weighing $\geqslant 1000 \mathrm{~g}$, however, reached significance $(p<0.004)$. The histidine concentrations were similar and within the normal range for all groups.

The non-essential amino acids proline and serine were higher in the group on Vamin 9 glucose $(p<0.0001$ and $p<0.003$ respectively). The aspartic acid concentrations were similar. Citrulline was significantly higher in the group on Vamin 9 glucose $(p<0.009)$ despite being in the normal range. The other non-essential amino acids were in the reference range and similar in the two groups.

Stepwise discriminant analysis was performed on the aminograms of the two treatment groups on day 5 , using threonine, serine, glutamate, proline, citrulline, methionine, tyrosine, and phenylalanine as the exploratory variables. Phenylalanine explained on its own some 55\% of the total variation between the two treatment
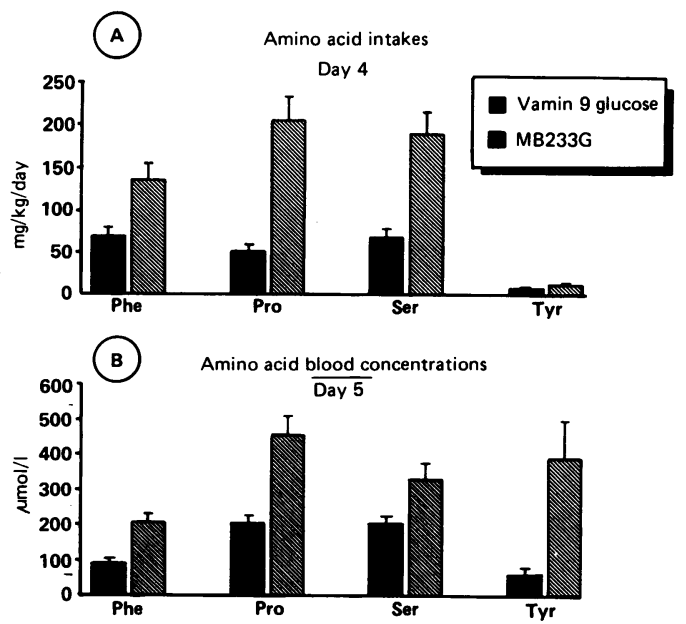

Figure 3(A) Intakes of four amino acids on day 4 and (B) amino acid concentrations on day 5. Phe: phenylalanine, pro: proline, ser: serine, tyr: tyrosine. groups but as the variability of these parameters was large, the same procedure was applied with ranked data. In this case proline, tyrosine, and serine accounted for $74 \%$ of the total variation and phenylalanine was no longer significant. These results reflect the intricacies of these variables which cannot be clarified further because of the relatively small sample size. The data confirms only that these four amino acids are most involved in the final differences between the two treatment groups.

In fig $3 \mathrm{~A}$ we have plotted the mean intakes of the four amino acids phenylalanine, proline, serine, and tyrosine in the $\mathbf{2 4}$ hours before the plasma analysis on day 5 (fig $3 B$ ). The higher plasma concentrations seem related to the higher intakes in the case of the first three amino acids. With tyrosine, however, there is no apparent association of plasma concentration to the previous day's intake.

\section{TOLERANCE}

A total of $18(78 \%)$ of the infants on MB233G and $23(92 \%)$ on Vamin 9 glucose were ventilated on entry to the study, and at the end of the study period $11(48 \%)$ on MB233G and 16 $(64 \%)$ on Vamin 9 glucose remained ventilated (difference not significant by $\chi^{2}$ test with Yates's correction). The oxygen requirements over the five days were similar in both groups.

Babies weighing $<1000 \mathrm{~g}$ fed on MB233G required parenteral nutrition for significantly less time (mean (SD) $8(4.8)$ days) than babies fed Vamin 9 glucose (13 (10 days), $\mathrm{p}<0.05$ ) (table 1).

Forty seven infusions were required in the 23 babies on MB233G and 54 in the 25 babies on the Vamin 9 glucose with 21 instances of drip infiltration in the group on MB233G and 29 in the group on Vamin 9 glucose.

Significantly higher blood glucose concentrations were seen on days 4 and 5 in the group on MB233G but these were related to two infants weighing less than $1000 \mathrm{~g}$ who received extra $5 \%$ dextrose to compensate for transcutaneous water losses.

The plasma sodium, potassium, calcium, phosphorus, and blood urea concentrations were all within the reference ranges and similar in both groups throughout the study.

The mean (SD) alanine aminotransferase, aspartate aminotransferase, and $\gamma$ glutamyltransferase activities of the two groups were similar on day 1 (alanine aminotransferase: Vamin 9 glucose 4.9 (2.9) U/1, MB233G 6.9 (6.1) U/1, $\mathrm{p}=0.2$; aspartate aminotransferase: Vamin 9 glucose $47.5(30.6) \mathrm{U} / 1, \mathrm{MB} 233 \mathrm{G} 30.8(23.8)$ $\mathrm{U} / \mathrm{l}, \mathrm{p}=0 \cdot 1$; and $\gamma$ glutamyltransferase: Vamin 9 glucose 62 (33) U/l, MB233G 79 (49) U/l, $p=0 \cdot 25$ ). On day 5, however, these liver enzymes were significantly higher in babies fed on Vamin 9 glucose (alanine aminotransferase: Vamin 9 glucose $11.3(9 \cdot 6) \mathrm{U} / 1, \mathrm{MB} 233 \mathrm{G} 3.7$ $(1 \cdot 1) \mathrm{U} / \mathrm{l}, \mathrm{p}<0.05$; aspartate aminotransferase: Vamin 9 glucose $33.0(18.4) \mathrm{U} / 1$, MB233G 16.4 $(10.3) \mathrm{U} / \mathrm{l}, \mathrm{p}<0.05$; and $\gamma$ glutamyltransferase 60 (28) U/l, MB233G 63 (66) U/1, p=0.9).

Both groups of infants were acidotic in conventional terms throughout the study period 
Table 6 Mortality

\begin{tabular}{|c|c|c|c|c|c|}
\hline & \multicolumn{2}{|l|}{$M B 233 G$} & \multicolumn{2}{|c|}{ Vamin 9 glucose } & \multirow{2}{*}{$\begin{array}{l}\text { Significance by } \\
\text { Fisher's exact tes }\end{array}$} \\
\hline & Total No & $\begin{array}{l}\text { No (\%) } \\
\text { who died }\end{array}$ & Total No & $\begin{array}{l}\text { No (\%) } \\
\text { who died }\end{array}$ & \\
\hline \multicolumn{6}{|c|}{ (a) By allocation to the study } \\
\hline $\begin{array}{l}<1000 \mathrm{~g} \\
\geqslant 1000 \mathrm{~g}\end{array}$ & $\begin{array}{l}11 \\
23\end{array}$ & $\begin{array}{l}3(27) \\
0\end{array}$ & $\begin{array}{l}16 \\
18\end{array}$ & $\begin{array}{l}5(31) \\
4(22)\end{array}$ & $\begin{array}{l}\text { NS } \\
\text { NS }\end{array}$ \\
\hline Total & 34 & $3(9)$ & 34 & $9(26)$ & NS \\
\hline \multicolumn{6}{|c|}{ (b) By completion of study protocol } \\
\hline $\begin{array}{l}<1000 \mathrm{~g} \\
\geqslant 1000 \mathrm{~g}\end{array}$ & $\begin{array}{r}7 \\
16\end{array}$ & $\begin{array}{l}\mathbf{0} \\
\mathbf{0}\end{array}$ & $\begin{array}{l}11 \\
14\end{array}$ & $\begin{array}{l}4(36) \\
4(29)\end{array}$ & $\begin{array}{l}\text { NS } \\
p<0.05\end{array}$ \\
\hline Total & 23 & 0 & 25 & $8(32)$ & $\mathrm{p}<0.01$ \\
\hline
\end{tabular}

but with values that were within the neonatal unit's reference range for babies with severe respiratory problems on ventilators. There was no significant difference between the two groups or apparent trend at a non-significant level (data submitted to editor and referees).

The haemoglobin concentration, white cell count, and platelets were as would be expected from the condition of these infants and were similar in the two groups.

\section{DEATHS}

Table 6 shows the mortality in the study, 6a by allocation of treatment and $6 \mathrm{~b}$ by completion of the study protocol. Four infants died before the study protocol was completed (three on MB233G and one on Vamin 9 glucose). These infants were all $<1000$ birth weight and all had respiratory problems related to their extreme prematurity. Two of the infants on MB233G and the single infant on Vamin 9 glucose had some evidence of infection though only one death (an extremely growth retarded infant, $480 \mathrm{~g}$ birth weight and 27 weeks' gestation) was thought to be directly related to pseudomonas septicaemia and pulmonary haemorrhage from coincident disseminated intravascular coagulation.

The deaths of the infants completing the study protocol were confined to the group on Vamin 9 glucose. Four infants $<1000 \mathrm{~g}$ birth weight died: one at 6 days (respiratory failure, septicaemia, and intra-abdominal haemorrhage), the second at 10 days (respiratory failure due to respiratory distress syndrome and intraventricular haemorrhage), the third at 17 days (respiratory failure due to respiratory distress syndrome with pulmonary interstitial emphysema and pneumothorax going on to bronchopulmonary dysplastic changes seen on radiography), and the fourth at 28 days (respiratory failure from chronic lung disease).

The other infants $(1000,1325,2500,3600 \mathrm{~g}$ birth weight) died at $10,20,28$, and 11 days respectively. All had respiratory distress syndrome and three had air leak during the early days of life. The two smaller infants of the four had intraventricular haemorrhages of grade 3 severity and patent ductus arteriosus and eventually died of infections. The larger two infants developed severe changes of bronchopulmonary dysplasia that were seen on radiography and died of respiratory failure.

The plasma amino acid concentrations of the infants in the group on Vamin 9 glucose that died were not significantly different on day 5 (the day of study completion) from the infants fed Vamin 9 glucose who went on to survive. The mean (SD) results were as followsphenylalanine: died 218 (82) $\mu \mathrm{mol} / \mathrm{l}$, alive 192 (62) $\mu \mathrm{mol} / \mathrm{l}$; tyrosine: died 452 (360) $\mu \mathrm{mol} / \mathrm{l}$, alive 312 (284) $\mu \mathrm{mol} / \mathrm{l}$; proline: died 476 (171) $\mu \mathrm{mol} / \mathrm{l}$, alive 426 (204) $\mu \mathrm{mol} / \mathrm{l}$; serine: died 314 (184) $\mu \mathrm{mol} / \mathrm{l}$, alive 327 (184) $\mu \mathrm{mol} / 1$; aspartic acid: died 69 (70) $\mu \mathrm{mol} / 1$, alive 49 (38) $\mu \mathrm{mol} / 1$. We unfortunately do not have measurements of either the plasma aminograms at a later stage, or the plasma ammonia concentrations as this was not part of the study protocol and we became aware of this apparent cluster of deaths after the trial only when the randomisation code was broken at the end of the study.

\section{Discussion}

The smaller and more immature the infant, the more crucial it is to provide adequate nutrition at a very early stage. It is commonplace now for very low birthweight infants to be given total or supplemental parenteral nutrition where any delay is expected in establishing enteral feeds. ${ }^{13}$ Most currently used amino acid preparations have not been prepared with the (premature) newborn in mind and have been accepted as satisfactory when the aminogram in the patient receiving the preparation has fallen in the reference range of full term and well infants either starved, ${ }^{1}$ fed on breast milk, ${ }^{2}$ or formula. ${ }^{3}$ It is possible that the nitrogen requirements of very immature infants will be more critical than in bigger and more mature infants because of greater metabolic immaturity and the absence of the safety valve of the placenta. Amino acid solutions with the wrong composition could produce potentially hazardous disturbances of blood chemistry such as a rise in the plasma concentrations of neurotoxic or hepatotoxic amino acids, metabolic acidosis, and hyperammonaemia.

The fetus in utero is not fed orally but is fed parenterally across the placenta. It is therefore reasonable to assume that the aminogram of the fetus in utero in the last trimester of pregnancy is unlikely to be toxic to the developing fetus and is probably satisfactory for the preterm or term newborn infant.

The aminograms of the mid trimester fetus have now been defined ${ }^{7}$ and are not significantly different from the cord blood amino acids 
of preterm and full term normal deliveries. ${ }^{45}$ The preparation MB233G is a new crystalline amino acid preparation that has been designed by Rigo et al to achieve plasma amino acid concentrations in these reference ranges. ${ }^{14} \mathrm{~A}$ previous observational study in our unit looked at the tolerance and efficacy of MB233G in 42 very low birthweight infants, 19 of whom were $<1000 \mathrm{~g}$ birth weight. We found no abnormal effects that we felt could be related to the preparation but in that study we were not comparing MB233G with another preparation. ${ }^{8}$ Vamin 9 glucose is a well tried $\mathrm{L}$ amino acid preparation used in the United Kingdom and Europe and more than $70 \%$ of the isomers are retained when infused $^{15}$; it contains no taurine or ornithine however. The absence of taurine may be important as taurine deficient diets (casein based parenteral nutrition solutions) in primates ${ }^{16}$ and humans $^{17}$ lead to retinal degeneration and abnormal electroretinograms. The absence of ornithine in the diet is not associated with any specific dysfunction but it is recognised as an essential amino acid. Both taurine and ornithine are present in MB233G. The only other qualitative difference in the two preparations is the cysteine which in Vamin 9 glucose is cystine whereas in MB233G it is cysteine hydrochloride. Whereas in the older infant and adult cysteine is a non-essential amino acid, it is thought to be essential in the preterm infant because the absence of cystathionase in the fetal and preterm infant's liver makes the usual conversion of methionine to cysteine unlikely. ${ }^{18}$

The randomisation and stratification of the groups shows them comparatively well matched for the size and maturity (table 1); however, there is an unfortunate trend towards the sicker infants with respiratory problems being allocated Vamin 9 glucose. This group (table 2) was more likely, both at study entry and completion, to require ventilation and three times as many infants in the group developed air leaks. None of these features reached significance but the differences in outcome in mortality (table 6) may be related to these features.

The nutritional intakes both parenterally and enterally were very similar in the two groups both at entry to the trial on day 1 and when the trial was concluded on the fifth day (table 3 ). Both preparations seemed clinically well tolerated during the five days of the study but infants $<1000 \mathrm{~g}$ fed Vamin 9 glucose required parenteral nutrition for a significantly longer period (table 1); this may be related to the babies in this group being sicker. Significantly more infants died in the period after study in the group receiving Vamin 9 glucose $(p<0.01$, table 6); this may also be related to the infants being sicker. Against this is the fact that the difference is largely accounted for by the excess of deaths in the group weighing $\geqslant 1000 \mathrm{~g}$ fed on Vamin 9 glucose (p 0.05) which are a group of infants more likely to be salvageable. We hypothesise that the deaths in the group on Vamin 9 glucose may be related to the high plasma concentrations of the aromatic amino acids phenylalanine and tyrosine, which are known to be neurotoxic with long term neurological sequelae. ${ }^{1921}$ The concentrations of phenylalanine in the group of infants on Vamin 9 glucose in this study (mean $187 \mu \mathrm{mol} / 1$, range 44-345) and the concentrations of tyrosine (mean $367 \mu \mathrm{mol} / \mathrm{l}$, range $46-925$ ) are up to five times higher than the upper limit of normal infants. The fetuses of phenylketonuric mothers (who can have phenylalanine concentrations in pregnancy of $600-900 \mu \mathrm{mol} / \mathrm{l}$ ) are usually mentally retarded and microcephalic, ${ }^{22}$ and the preterm infants of this study are going through a similar phase of extremely rapid brain growth. Abnormal concentrations of phenylalanine have been reported before but were thought to be related to extreme immaturity. ${ }^{9-12}$ The concentrations in the babies on Vamin 9 glucose were similar in infants stratified above and below $1000 \mathrm{~g}$, suggesting that immaturity might not be the sole problem. The plasma concentrations of tyrosine were also extremely high in the group on Vamin 9 glucose compared with the reference range (36-90 $\mu \mathrm{mol} / \mathrm{l})$ and were often at concentrations seen in transient tyrosinaemia. ${ }^{20}$ Intellectual deficits were shown in term neonates with this condition by Menkes et al in $1966^{19}$ and by Mamunes et al in $1976,{ }^{20}$ but Martin et al could not demonstrate abnormality in six infants followed up to six years. ${ }^{23}$ The severe mental retardation associated with the autosomal recessive form of tyrosinaemia known as the Richner-Hanhart syndrome is preventable by the use of low tyrosine diets and the plasma tyrosine concentrations in untreated patients with this condition are similar to the concentrations seen in the infants on Vamin 9 glucose. The data in figure 3 suggest that the phenylalanine blood concentrations may be related to the amino acid intake but the high tyrosine concentrations seen in the group on Vamin 9 glucose, which were over four times those of the group on MB233G, occurred even though the intake of tyrosine in the 24 hours before sampling was the same. It appears that the tyrosine is not utilised in the group on Vamin 9 glucose and we hypothesise that this may be because of the high plasma concentrations of phenylalanine, proline, serine, or aspartic acid interfere with effective liver function. The discriminant analysis of the raw data suggests that the phenylalanine concentrations may be the primary cause of this problem.

Against the hypothesis that the high plasma amino acid concentrations were in some way associated with the deaths is the apparent lack of clinical toxicity of the preparation Vamin 9 glucose and the fact that the amino acid concentrations of the survivors were no different on day 5 in that group whether they went on to survive or die. It is noteworthy that some liver cell function tests were significantly higher on day 5 of the infusion in this group. Because the trial finished after five days of infusion we have no further measurements of plasma amino acids or of ammonia concentrations but many of the infants in both groups continued with their intravenous nutrition after their formal study period. The deaths when assessed clinically do not fit into any uniquely similar pattern but display the characteristics of very sick preterm infants requiring intensive care.

Both groups in this study had identical and 
adequate ascorbic acid intakes $(250 \mathrm{mg} / \mathrm{kg} / \mathrm{day})$ so that restricted availability of the cofactor for tyrosine transferase activity is unlikely to account for the accumulation of tyrosine or phenylalanine in the group on Vamin 9 glucose.

The additional taurine in the MB233G did not lead to higher plasma taurine concentrations in this group and the mean taurine concentrations in both groups of babies weighing less than $1000 \mathrm{~g}$ were lower than the lower limit of the reference range. In the group on Vamin 9 glucose some infants had extremely low plasma concentrations. It is possible that the taurine content in MB233G prevented such low concentrations.

We conclude from this study that preparation MB233G maintains the plasma aminogram more closely within the normal reference range related to cord blood amino acid concentrations than does Vamin 9 glucose where the plasma phenylalanine, tyrosine, proline, serine, and aspartic acid are high independent of the weight of the infant.

Although during the study both preparations seemed well tolerated, the excess mortality in the group on Vamin 9 glucose after the end of the study period must be noted and although it may be related to sicker infants being present in this group, the association is independent of birth weight and is coincident with high plasma amino acid concentrations of some known neurotoxic and hepatotoxic amino acids. This must remain a cause of concern until the study can be repeated by others.

The authors wish to thank the nursing and medical staff of the neonatal unit for their dedicated care of the infants in this study Mr I McDonald and the pharmacy for the preparation an double blind allocation of the product and Mrs F Oliver (Edinburgh) for preparation of the manuscript. We would also like to thank Cernep Synthelabo (France) for supplying MB233G

I Dickinson JC, Rosenblum H, Hamilton PB. Ion-exchange chromatography of the free amino acids in the plasma of the chromatography of the free amino acids in the

2 Pohlandt F. Plasma amino acid concentrations in newborn infants breast-fed ad libitum. $\mathcal{F}$ Pediatr 1978;92:614-6.

3 Zlotkin SH, Bryan MH, Anderson GH. Intravenous nitrogen and energy intakes required to duplicate in utero nitrogen accretion in prematurely born human infants. $f$ Pediatr 1981;99:115-20.

4 Cockburn F, Robins SP, Forfar JO. Free amino-acid concentrations in fetal fluids. $\mathrm{Br}$ Med $\mathcal{J}$ 1970;iii:747-50.

5 Rigo J. Contribution a l'étude de l'apport optimal en acides aminés chez le prématuré alimenté par voie orale on parentérale. aminés chez le prématuré alimente par : University of Liege, 1980:1-24. (Thesis.)

6 McIntosh N, Rodeck CH, Heath R. Plasma amino acids of the mid-trimester human fetus. Biol Neonate 1984;45: 218-24.

7 Soltész G, Harris D, Mackenzie IZ, Aynsley-Green A. The metabolic and endocrine milieu of the human fetus and mother at 18-21 weeks of gestation: I. Plasma and amino acid concentrations. Pediatr Res 1985;19:91-3.

8 McIntosh N, Ventura V, Kempson C. The tolerance of a new amino acid preparation for intravenous nutrition in very low birth weight infants. Fournal of Intensive Therapy and Clinical Monitoring (in press).

9 Puntis JWL, Ewards MA, Green A, Morgan I, Booth IW, Ball PA. Hyperphenylalaninaemia in parenterally fed newborn babies. Lancet 1986;ii:1105-6.

10 Mitton SG, Burston D, Brueton MJ. Hyperphenylalaninaemia in parenterally fed newborn infants. Lancet 1988 ; ii: $1497-8$.

11 Walker V, Hall MA, Bulusu S, Allan A. Hyperphenylalaninaemia in parenterally fed newborn babies. Lancet 1986; ii: 1284

12 Salle B, Rigo J, Senterre J, Putet G, Claris-Meunier G. Alimentation parentérale supplétive chez le prématuré. Arch Fr Pediatr 1987;44:5-8.

$13 \mathrm{Yu}$ VYH. Parenteral nutrition in the newborn. In: Robertson NRC, ed. Textbook of neonatology. Edinburgh: Churchill Livingstone, 1986:211-22.

14 Rigo J, Senterre J, Putet G, Salle B. A new amino acid solution specially adapted to preterm infants. Clinical Nutrition 1987;6:105-9.

15 Duffy B, Gunn T, Collinge J, Pencharz P. The effect of varying protein quality and energy intake on the nitrogen metabolism of parenterally fed low birthweight $(1600 \mathrm{~g})$ infants. Pediatr Res 1981;15:1040-4.

16 Sturman JA, Wen GY, Wisniewski HM. Retinal degeneration in primates raised on a synthetic human infant formula. International fournal of Developmental Neurosciences 1984;2:121-9.

17 Geggel HS, Heckenlively JR, Matin DA, et al. Human retinal dysfunction and taurine deficiency. Doc Opthalmol 1982;

18 Gaull G, Sturman JA, Raiha NCR. Development of mammalian sulfur metabolism. Absence of cystathionase in human fetal tissues. Pediatr Res 1976;6:538-47.

19 Menkes JH, Chernick V, Ringel MA. Effect of elevated blood tyrosine on subsequent intellectual development of premature infants. F Pediatr 1966;69:583-8.

20 Mamunes P, Prince PE, Thornton NH, Hunt PA, Hitchcock ES. Intellectual deficits after transient tyrosinemia in the term neonate. Pediatrics 1976;57:675-80.

21 Tourian AY, Sidbury JB. Phenylketonuria. In: Stanbury JB, Wyngaarden JB, Fredrickson DS, eds. The metabolic basis of inherited disease. 4th Ed. New York: McGraw Hill, 1978: $240-55$.

22 Lenke RR, Levy HL. Maternal phenylketonuria and hyperphenylalaninemia: an international survey of the outcome phenylalaninemia: an international survey of the outcome
of untreated and treated pregnancies. $N$ Engl $\mathcal{F}$ Med 1980; of untreated

23 Martin HP, Fischer HL, Martin DS, Chase HP. The development of children with transient neonatal tyrosinemia. $\mathcal{J}$ Pediatr 1974;84:212-6. 